\title{
A reassessment of the contribution of soybean biological nitrogen fixation to reactive $\mathrm{N}$ in the environment
}

\author{
Ilya Gelfand • G. Philip Robertson
}

Received: 26 May 2014/ Accepted: 8 December 2014/Published online: 21 December 2014

(C) The Author(s) 2014. This article is published with open access at Springerlink.com

\begin{abstract}
The expansion of soybean (Glycine max (L.) Merr) acreage, increasing yields, and recent nitrogen $(\mathrm{N})$ fertilization recommendations could have a major effect on the contribution of biological $\mathrm{N}$ fixation $(B N F)$ in soybeans to reactive nitrogen $\left(\mathrm{N}_{\mathrm{r}}\right)$ in the environment. We used ${ }^{15} \mathrm{~N}$ natural abundance to separate fixed $\mathrm{N}$ into grain, aboveground vegetative biomass, and roots along a 9-point $\mathrm{N}$-fertilizer gradient to ask: 1) is the belowground BNF contribution sufficiently different from aboveground to affect regional estimates of soybean $\mathrm{N}_{\mathrm{r}}$ production based on harvested biomass, and 2) how does $\mathrm{N}$ fertilizer affect soybean yield and BNF's contribution to different tissues? The contribution of root and vegetative
\end{abstract}

Responsible Editor: Kate Lajtha.

I. Gelfand $(\bowtie) \cdot$ G. Philip Robertson

W.K. Kellogg Biological Station, Michigan State

University, Hickory Corners, MI 49060, USA

e-mail: ilya.gelfand@kbs.msu.edu

I. Gelfand · G. Philip Robertson

Great Lakes Bioenergy Research Center, Michigan State

University, East Lansing, MI 48824, USA

G. Philip Robertson

Department of Plant, Soil, and Microbial Sciences,

Michigan State University, East Lansing, MI 48824, USA biomass to overall plant BNF was five times lower than that for grain. Including this difference in BNF

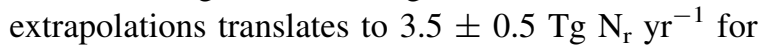
total US soybean production, $\sim 37 \%$ lower than earlier estimates that did not differentiate tissue source. Production of $\mathrm{N}_{\mathrm{r}}$ ranged between $35 \pm 11$ and $73 \pm 5 \mathrm{~g} \mathrm{Nr} \mathrm{kg}^{-1}$ grain and was affected by both fertilization and irrigation. In all cases $\mathrm{N}$ credits to the next rotational crop were minor. $\mathrm{N}$-fertilization at even very low levels (17-50 $\mathrm{kg} \mathrm{N} \mathrm{ha}^{-1}$ ) did not affect yield, but grain $\mathrm{N}$ content increased with fertilizer level. The percent $\mathrm{BNF}$ contributed to plant $\mathrm{N}$ decreased linearly with increasing fertilization, in grain from $49 \pm 8 \%$ in unfertilized plots to a plateau of $16 \pm 6 \%$ at fertilization $\geq 85 \mathrm{~kg} \mathrm{~N} \mathrm{ha}^{-1}$; in aboveground vegetative biomass from $77 \pm 4 \%$ to a plateau of $11 \pm 11 \%$ at $146 \mathrm{~kg} \mathrm{~N} \mathrm{ha}^{-1}$; and in roots from $88 \pm 12 \%$ to a plateau of $41 \pm 6 \%$ at $146 \mathrm{~kg} \mathrm{~N} \mathrm{ha}^{-1}$. The average whole-plant BNF contribution decreased from $\sim 84 \%$ in unfertilized plots to a plateau of $\sim 34 \%$ at fertilization rates greater than $84 \mathrm{~kg} \mathrm{ha}^{-1}$. Results underscore the unnecessary expense and environmental burden of adding $\mathrm{N}$ fertilizer to modern soybean varieties, and provide a refined lower estimate for the contribution of soybean $\mathrm{N}$ fixation to the US and global $\mathrm{N}_{\mathrm{r}}$ budgets of 3.5 and 10.4 $\mathrm{Tg} \mathrm{Nr}_{\mathrm{yr}}{ }^{-1}$, respectively.

Keywords Nitrogen uptake $\cdot{ }^{15} \mathrm{~N}$ natural abundance $\cdot$ Legumes $\cdot$ Roots $\cdot$ Yield response · Irrigation 


\section{Introduction}

Soybean is an important agricultural crop with a large and expanding cropping area globally. In the U.S., for example, from 1990 to 2013 average US soybean yields increased by $\sim 20 \%$ from $2.2 \mathrm{Mg} \mathrm{ha}^{-1} \mathrm{yr}^{-1}$ in 1990 to $\sim 2.7 \mathrm{Mg} \mathrm{ha}^{-1} \mathrm{yr}^{-1}$ in 2013 , and acreage increased by $\sim 36 \%$ from $\sim 23 \times 10^{6}$ ha in 1990 to $31 \times 10^{6}$ ha in 2013 (USDA NASS 2014). Moreover, soybean agriculture has undergone rapid expansion around the globe; in Brazil, soybean cropped areas exceeded $25 \times 10^{6}$ ha in 2012 , compared to less than $15 \times 10^{6}$ ha only a decade before (Alves et al. 2003; FAO 2007; Soystat 2013). The expansion of soybean acreage, together with increasing yields, could have significant implications for $\mathrm{N}_{\mathrm{r}}$ inputs to the environment (Martinelli et al. 2006) owing to the loss of newly fixed $\mathrm{N}$ into waterways, aquifers, and the atmosphere.

Estimates of $\mathrm{N}_{\mathrm{r}}$ production due to soybean cultivation are uncertain, although agricultural systems with $\mathrm{BNF}$ as a major source of new $\mathrm{N}$ tend to have lower $\mathrm{N}$ surplus and thus appear to lose less nitrate than systems with high $\mathrm{N}$ fertilizer inputs (Blesh and Drinkwater 2013; Syswerda et al. 2012). Current global estimates of $\mathrm{N}_{\mathrm{r}}$ loss from soybeans are based on reported yields, the grain to biomass ratio, and the contribution of BNF to total soybean biomass N. Four major assumptions are inherent: 1) the $\mathrm{N}$ content of non-grain above- and belowground biomass is $3 \% ; 2$ ) the harvest index of soybean plants (the grain: total aboveground biomass ratio) is $0.4 ; 3$ ) the ratio of aboveground $\mathrm{N}$ to total crop $\mathrm{N}$ content is 1.5 ; and 4 ) $68 \%$ of total plant $\mathrm{N}$ is provided from BNF $(\mathrm{N}$ delivered from the atmosphere, or Ndfa) (Peoples et al. 1995a, b; Herridge et al. 2008). This last assumption is particularly uncertain because the contributions of belowground and aboveground vegetative biomass to total plant $\mathrm{Ndfa}$ and therefore to $\mathrm{N}_{\mathrm{r}}$ production can be much lower than that of grain. If so, $\mathrm{N}_{\mathrm{r}}$ production by soybeans might be significantly overestimated.

Moreover, the effect and fate of $\mathrm{N}$ fertilizer added to soybeans, currently recommended by the International Plant Nutrition Institute (2014) and others (Pioneer 2014; University of Minnesota 2014) to be added at a rate of $\sim 50 \mathrm{~kg} \mathrm{~N}^{-1}$ for high yielding varieties based on evidence reviewed by Salvagiotti et al. (2008), is unknown. Is BNF reduced in the presence of fertilizer $\mathrm{N}$ as theory predicts or does moderate fertilization, especially during early development, increase Ndfa over the full growing cycle (van Kessel and Hartley 2000; Ruiz Diaz et al. 2009)?

Altogether, these uncertainties lead to a very wide range of estimates of the contribution of BNF by crop legumes to the global N cycle (e.g., Smil 1999; Galloway et al. 2004; Herridge et al. 2008), with estimates ranging between 10 and $32 \mathrm{Tg} \mathrm{N}_{\mathrm{r}} \mathrm{yr}^{-1}$. Compared to natural, pre-industrial $\mathrm{N}$ fixation of $\sim 58$ $\mathrm{Tg} \mathrm{N} \mathrm{yr}^{-1}$ (Vitousek et al. 2013) this range represents between 20 and $\sim 50 \%$ increase in the global $\mathrm{N}_{\mathrm{r}}$ pool due to soybean BNF.

Many studies provide estimates of the contribution of BNF to aboveground soybean biomass (including both grain and shoots), which, on average, accounts for $\sim 60 \%$ of total soybean $\mathrm{N}$ uptake (Salvagiotti et al. 2008). This generalized estimate of the contribution of BNF to the total $\mathrm{N}$ budget of soybeans has been reported across a range of environmental and soil conditions. A few studies, however, have reported higher rates of up to $80 \%$ in Brazil (Alves et al. 2003) and Argentina (e.g., Herridge et al. 2008), where soybeans have been bred on unfertilized soils.

By contrast, assessments of belowground BNF contributions (root Ndfa) are sparse and lower. The contribution of belowground BNF to the whole plant $\mathrm{N}$ balance at maturity range from $\sim 24$ to $\sim 40 \%$ for irrigated and dryland soybeans in Australia (Rochester et al. 1998; Unkovich and Pate, 2000). By including Australian estimates of belowground fixed N, Herridge et al. (2008) updated the $\sim 10 \mathrm{Tg} \mathrm{N} \mathrm{Nr}^{-1}$ estimate by Smil (1999) to $16.4 \mathrm{Tg} \mathrm{N}_{\mathrm{r}} \mathrm{yr}^{-1}$.

Soybeans can also meet their $\mathrm{N}$ needs from soil inorganic $\mathrm{N}$ pools. Because BNF is energy intensive (Silsbury 1977), soybeans are expected to favor inorganic $\mathrm{N}$ uptake when $\mathrm{N}$ availability in soil increases (Peoples et al. 1995b; Schipanski et al. 2010). This expectation for a changing contribution of BNF to the aboveground biomass has been tested in field studies. Using the ${ }^{15} \mathrm{~N}$ natural abundance method, Schipanski et al. (2010) showed a quadratic-like decrease in the $\mathrm{BNF}$ contribution with an increase in soil $\mathrm{N}$ availability in fields under legume vs. fertilizer $\mathrm{N}$ management. In a direct fertilization experiment, with the addition of between 0 and $180 \mathrm{~kg} \mathrm{~N} \mathrm{ha}^{-1}$ in four increments, Goss et al. (2002) showed a linear decrease in BNF with increasing $\mathrm{N}$ fertilization. After reviewing over 50 studies over the past 40 years in which $\mathrm{N}$ fertilizer was added (ranging between 0 and $1,800 \mathrm{~kg} \mathrm{~N} \mathrm{ha}^{-1}$ ), 
Salvagiotti et al. (2008) drew a highly scattered negative exponential relationship between fertilization and the total fixed $\mathrm{N}$ in soybean aboveground biomass. We are aware of no studies that have examined the differential responses of above versus belowground $\mathrm{Ndfa}$ to increasing $\mathrm{N}$ fertilization rates.

At least two questions remain: 1) is the belowground contribution to soybean Ndfa sufficiently different from the aboveground contribution to affect regional estimates of soybean $\mathrm{N}_{\mathrm{r}}$ production based on harvested biomass; and 2) how does $\mathrm{N}$ fertilizer affect soybean yield and the Ndfa in different plant parts? We investigated these questions at a site in SW Michigan, USA, where we fertilized a modern commercial transgenic soybean variety at nine different $\mathrm{N}$ levels ranging from 0 to $146 \mathrm{~kg} \mathrm{~N} \mathrm{ha}^{-1}$. We further compare rates of BNF in an irrigated non-fertilized check plot and in a conventionally managed tilled system that received starter fertilizer of $9 \mathrm{~kg} \mathrm{~N} \mathrm{ha}^{-1}$.

\section{Materials and methods}

\section{Experimental site and design}

The experimental site is located in SW Michigan in the northeast portion of the U.S. Corn Belt, at the W.K. Kellogg Biological Station (KBS) Long-Term Ecological Research (LTER) site (www.lter.kbs.msu.edu; Robertson and Hamilton 2015) $\left(42^{\circ} 24^{\prime} \mathrm{N}, 85^{\circ} 24^{\prime} \mathrm{W}\right.$ at 288 m elevation). The mean annual air temperature at $\mathrm{KBS}$ is $9.7^{\circ} \mathrm{C}$ and annual rainfall averages $900 \mathrm{~mm} \mathrm{yr}^{-1}$, evenly distributed seasonally with about half falling as snow. Soils are well-drained Typic Hapludalfs developed on glacial outwash. During the experimental year (2012), the summer was drier than usual with $226 \mathrm{~mm}$ of total precipitation between soybean planting (22 May) and harvest (9 October) compared to a long-term average of $369 \mathrm{~mm}$ (NOAA 2009; lter.kbs.msu.edu/datatables/7). Daily temperature averages ranged between $13.4 \pm 5.0$ (minimum) and $27.1 \pm 5.8{ }^{\circ} \mathrm{C}$ (maximum).

The experimental plots are part of the LTER resource gradient experiment established in 2005 (Robertson and Hamilton 2015). The plots are $4.6 \times 27.4 \mathrm{~m}$ arranged randomly in eight blocks (four rainfed and four irrigated). The plots received standard potassium $\left(\mathrm{K}_{2} \mathrm{O}\right)$ and phosphorus $\left(\mathrm{PO}_{4}^{-}\right)$fertilization $(130 \mathrm{~kg} \mathrm{~K}$ $\mathrm{ha}^{-1}$ and $73-123 \mathrm{~kg} \mathrm{P} \mathrm{ha}^{-1}$ based on soil tests), with lime also applied as needed $\left(2-5 \mathrm{Mg} \mathrm{ha}^{-1}\right)$ to moderate soil $\mathrm{pH}$. All plots are in the same corn-soybean-wheat rotation. Although soybeans are normally not differentially fertilized in this rotation, for this experiment soybeans were treated with nine $\mathrm{N}$ fertilization levels: 0 , $17,34,50,67,84,101,123$, and $146 \mathrm{~kg} \mathrm{~N}^{-1}$ as granular ammonium-nitrate (38-0-0; treatments F0F146, respectively) on 14 June, prior to the R1 development stage. None of the plots were tilled.

We examined BNF in all rainfed $\mathrm{N}$ fertilization treatments and in the unfertilized irrigated treatment. Additionally, we examined BNF in four replicate 1 ha plots under conventional management (i.e., chemical inputs and soil preparation) within the KBS LTER Main Cropping System Experiment (MCSE; Robertson and Hamilton 2015). The conventionally managed plots in the MCSE received $9 \mathrm{~kg} \mathrm{~N}^{-1}$ as part of a starter NPK fertilizer application per normal farming practices in Michigan.

Plant sampling and analysis

We planted in all experimental plots a commercially available soybean variety (Pioneer 92Y30 RR) and for reference five soybean plants of a non-nodulating isoline (PI 547695, seed source: 04U-3266; Horosoy) obtained from the USDA Soybean Germplasm Collection (USDA-ARS, Urbana, IL). The nodulating plants were sown using standard field equipment; to sow the non-nodulated plants we manually removed commercial seeds from soil and exchanged them with non-nodulating seeds.

Ten plants (5 nodulating and 5 non-nodulating) were harvested by hand at full seed stage (R6.5). We harvested whole plants, together with the majority of coarse and fine roots, by collecting all the soil within a $25 \times 25 \mathrm{~cm}$ wide $\times 25 \mathrm{~cm}$ depth soil volume. Soil was carefully shaken from the roots in the field, and the roots were examined for the presence or absence of nodules. Then the roots were placed on a $4 \mathrm{~mm}$ screen and washed with sprinkled water to remove soil. All plants from the same replicate plot were composited. Plant material was then divided into three major components: grain, aboveground vegetative biomass (stem, leaves, and pods less seeds) and belowground biomass (roots including nodules). These three components represent different pathways of $\mathrm{N}_{\mathrm{r}}$ flow: grain is removed from the field and used for food/feed; aboveground vegetative biomass is dispersed across 
the field during harvest; and belowground biomass decomposes in place in the field.

Plant components were oven dried to a stable weight at $60{ }^{\circ} \mathrm{C}$ and then weighed and ground to pass a $200 \mu \mathrm{m}$ mesh sieve. Then subsamples were weighed in duplicate into tin cups and sent for ${ }^{15} \mathrm{~N}$ natural abundance and total $\mathrm{N}$ content analysis (Stable Isotope Facility, UC Davis, USA).To correct for percent ash in samples we measured ash by burning subsamples in a muffle furnace at $550{ }^{\circ} \mathrm{C}$ for at least $4 \mathrm{~h}$ and weighed the residue as total ash.

\section{Nitrogen fixation estimation}

We used the ${ }^{15} \mathrm{~N}$ natural abundance method (Schipanski et al. 2010) to estimate BNF in soybeans. The percentage of BNF in the $\mathrm{N}$-fixing (nodulated; $\mathrm{N}_{\text {fix }}$ ) soybean (Pioneer) biomass was calculated using the non-nodulating (nonN) soybeans as reference plants:

$\% \mathrm{~N}$ fixation $=100$

$$
\times\left[\left(\delta^{15} \mathrm{~N}_{\text {nonN }}-\delta^{15} \mathrm{~N}_{\mathrm{Nfix}}\right) /\left(\delta^{15} \mathrm{~N}_{\text {nonN }}-B\right)\right]
$$

where $\delta^{15} \mathrm{~N}_{\text {nonN }}$, and $\delta^{15} \mathrm{~N}_{\mathrm{Nfix}}$ are $\delta^{15} \mathrm{~N}$ values of nodulating and non-nodulating plants, respectively and $B$ is the $\delta^{15} \mathrm{~N}$ value of soybean grown with atmospheric $\mathrm{N}$ as the only source of $\mathrm{N}$. The total fixed $\mathrm{N}$ in each component of the plant was calculated from the dry matter, $\mathrm{N}$ concentration, and $\% \mathrm{~N}$ from fixation.

To quantify $B$, we grew in $\mathrm{N}$-free media in the greenhouse 24 plants of the commercial varieties Pioneer 92Y30 RR and Blue Rive Hybrids Certified organic (OCIA) in 12 pots containing a mixture of sand, Turface MPV (Profile products, Buffalo Grove, IL, USA), and perlite; seven pots had Pioneer and five pots had Blue River hybrids. We inoculated each pot with a $10 \mathrm{ml}$ slurry made of a bulked soil sample taken prior to planting from all experimental plots and combined with distilled water in a 1:3 proportion. The plants were fertilized with $\mathrm{N}$-free Hoagland's nutrient solution (0-7-5 NPK with micronutrients; GreenCare Fertilizers, Chicago, IL, USA). The plants grown in the greenhouse were harvested and analyzed for $\delta^{15} \mathrm{~N}$ in the same way as the field plants.

\section{Yield and $\mathrm{N}$ balance estimation}

For yield determinations soybeans in all plots were harvested on 9 October using standard field equipment.
For estimating the effect of water limitation on soybean yields we compared yields of non-irrigated plots to irrigated plots in the current year and to non-irrigated plots in 2009. In 2009, the precipitation during the soybean growing season was $382 \mathrm{~mm}$ (compared to $226 \mathrm{~mm}$ for the 2012 growing season) and the minimum and maximum average daily temperatures were $12.2 \pm 4.0$ (mean \pm S.D.) and $24.4 \pm 4.6{ }^{\circ} \mathrm{C}$, respectively, as compared to $13.4 \pm 5.0$ and $27.1 \pm 5.8^{\circ} \mathrm{C}$ in 2012.

To calculate $\mathrm{N}_{\mathrm{r}}$ production due to soybean cultivation in the US we determined the average plant population density for the conventionally managed treatment at harvest $\left(329 \times 10^{3} \pm 18 \times 10^{3}\right.$ plants $\mathrm{ha}^{-1}$ ). Then we used Ndfa values for the conventional treatment, except for roots. For roots we substituted the average Ndfa value for F0 and F17 (Fig. 1c).

The $\mathrm{N}$ balances for experimental treatments were calculated as the difference between the sum of $\mathrm{N}$ from the soil $\left(\right.$ Soil $\left._{\mathrm{N}}\right)$ and $\mathrm{N}$ fixation $\left(\mathrm{BNF}_{\mathrm{N}}\right)$ and harvested $\mathrm{N}$ (Harvest $\mathrm{N}_{\mathrm{N}}$ ) (Eq. 2). For the calculation of $\mathrm{N}_{\mathrm{r}}$, we added $\mathrm{N}$ inputs from fertilization $\left(\right.$ Fert $_{\mathrm{N}}$ ) and $\mathrm{BNF}_{\mathrm{N}}$ (Eq. 3), and to calculate the $\mathrm{N}$ credit, we subtracted harvested $\mathrm{N}$ from $\mathrm{N}_{\mathrm{r}}$ (Eq. 4):

$\mathrm{N}$ balance $=\left[\right.$ Soil $\left._{\mathrm{N}}+\mathrm{BNF}_{\mathrm{N}}\right]-$ Harvest $_{\mathrm{N}}$

$\mathrm{N}_{\mathrm{r}}=\mathrm{BNF}_{\mathrm{N}}+$ Fert $_{\mathrm{N}}$

$\mathrm{N}$ credit $=\left[\mathrm{BNF}_{\mathrm{N}}+\right.$ Fert $\left._{\mathrm{N}}\right]-$ Harvest $_{\mathrm{N}}$

To calculate $\mathrm{N}$ balance, $\mathrm{N}_{\mathrm{r}}$, and $\mathrm{N}$ credit for the F84 treatment we substituted root $\mathrm{BNF}_{\mathrm{N}}$ with the roots Ndfa from F34 to F123 (Fig. 1c).

\section{Results}

Contribution of BNF to $\mathrm{N}$ content in grain, aboveground, and belowground biomass

All reference plants grown in the greenhouse showed nodulation and exhibited very similar $\delta^{15} \mathrm{~N}$ values irrespective of the commercially available cultivar: grain, $-1.50 \pm 0.05 \%$ ( \pm standard error, $n=12$ pots); aboveground vegetative biomass, $-2.78 \pm$ $0.10 \%$ ( \pm standard error, $n=12$ ); belowground biomass, $5.30 \pm 0.29 \%$ ( \pm standard error, $n=11)$. The nitrogen contents of these plants were: grain, $5.79 \pm$ $0.12 \%$ ( \pm standard error, $n=12$ ); aboveground 


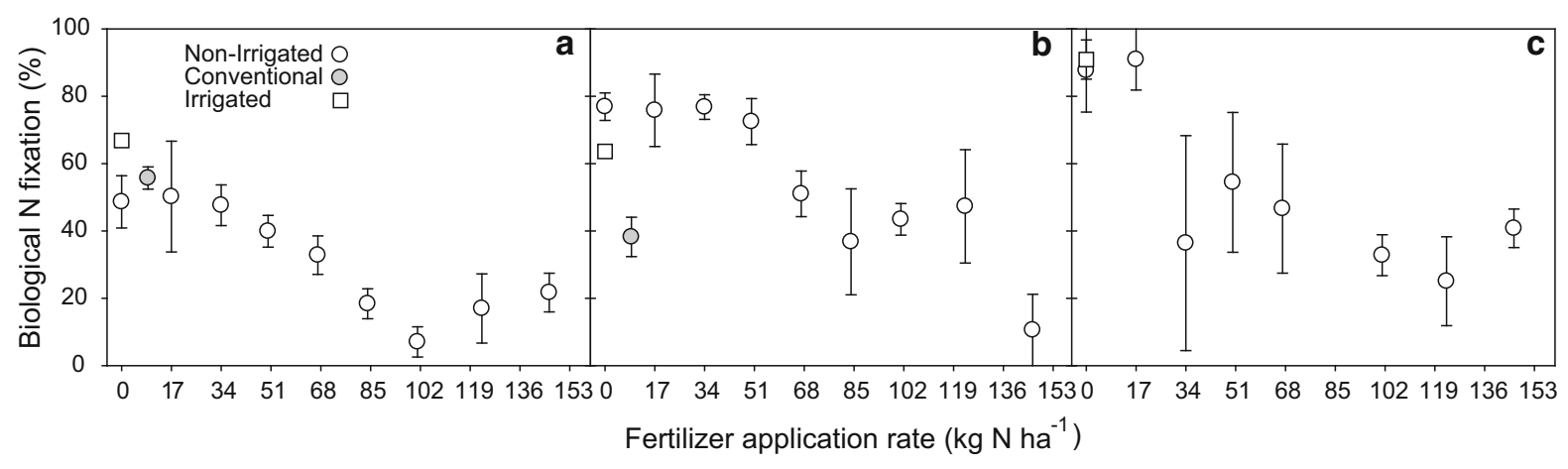

Fig. 1 Contribution of $\mathrm{BNF}(\%)$ to the $\mathrm{N}$ content of a harvested grain, $\mathbf{b}$ aboveground vegetative biomass, and $\mathbf{c}$ roots of soybean plants as a function of the $\mathrm{N}$ fertilizer application rate in nonirrigated no-till plots (open circles), Conventionally managed

vegetative biomass, $1.80 \pm 0.11 \%$ ( \pm standard error, $n=12$ ); and belowground biomass, $2.49 \pm 0.07 \%$ ( \pm standard error, $n=11$ ).

Biological nitrogen fixation contributed $49 \pm 8 \%$ to the $\mathrm{N}$ content of grain in all rainfed treatments with no $\mathrm{N}$ fertilizer and as little as $22 \pm 6 \%$ at high fertilizer levels (Fig. 1a; $146 \mathrm{~kg} \mathrm{~N} \mathrm{ha}^{-1}$ ). In the irrigated treatment $\mathrm{BNF}$ contributed $67 \pm 2 \%$ to total $\mathrm{N}$ content of the grain. The contributions of $\mathrm{N}$ fixation to grain $\mathrm{N}$ content exhibited a linear decrease with fertilizer $\mathrm{N}$ level, reaching a plateau of $16 \pm 6 \%$ at fertilization levels between 84 and $146 \mathrm{~kg} \mathrm{~N}^{-1}$ (Fig. 1a). Over all fertilization levels, the relative contribution of grain $\mathrm{N}$ originated from BNF to total plant Ndfa averaged $84 \pm 3 \%$ (Table 1).

In the aboveground vegetative (non-grain) portions of rainfed plants, the contribution of $\mathrm{BNF}$ to $\mathrm{N}$ content exhibited a different pattern. BNF contributed $\sim 80 \%$ to the total vegetative $\mathrm{N}$ content in treatments fertilized at rates between 0 and $50 \mathrm{~kg} \mathrm{~N} \mathrm{ha}^{-1}, \sim 50 \%$ in treatments fertilized between 67 and $123 \mathrm{~kg} \mathrm{~N} \mathrm{ha}^{-1}$, and reached a minimum of $\sim 11 \%$ at the application rate of $146 \mathrm{~kg} \mathrm{~N} \mathrm{ha}^{-1}$ (Fig. 1b). Biological $\mathrm{N}$ fixation contributed between 60 and $40 \%$ to the aboveground vegetative biomass in the unfertilized irrigated plots and in the conventionally managed plots, respectively (Fig. 1b). The relative contribution of aboveground vegetative biomass $\mathrm{N}$ originated from $\mathrm{BNF}$ to total plant Ndfa averaged $12 \pm 2 \%$ (Table 1).

The BNF contribution to the total $\mathrm{N}$ content of roots exhibited a linear decrease with increasing fertilization rates. Over all treatments, BNF contributed to total root $\mathrm{N}$ between $\sim 91 \pm 6 \%$ in the unfertilized plots including tillage and starter fertilizer (shaded circles), and Irrigated and unfertilized no-till plots (open squares) (mean \pm s.e. $n=4$ )

plots and $41 \pm 6 \%$ at $120 \mathrm{~kg} \mathrm{~N} \mathrm{ha}^{-1}$ (Fig. 1c). However, the relative contribution of root biomass $\mathrm{N}$ originated from BNF to total plant Ndfa averaged $4 \pm 1 \%$ (Table 1$)$.

In rainfed treatments, the shoot to root ratio was $2.3 \pm 0.1$, while in irrigated treatments the shoot to root ratio was $4.9 \pm 0.3$. Overall, the grain to total biomass ratio (including belowground biomass) was $1.0 \pm 0.0$, and the harvest index (grain to aboveground biomass ratio) was $0.5 \pm 0.0$ in all studied treatments.

Yield and $\mathrm{N}$ content of plants in response to fertilization and irrigation

Measured yields exhibited no response to fertilization; average of non-irrigated plots $2.6 \pm 0.1 \mathrm{Mg}$ grain ha ${ }^{-1}$ (Fig. 2). Irrigated plots yielded $5.1 \pm 0.1 \mathrm{Mg}$ grain $\mathrm{ha}^{-1}$ also with no response to fertilization (Fig. 2). In contrast, grain $\mathrm{N}$ content exhibited a linear increase with increasing $\mathrm{N}$ fertilization (Fig. 3). Grain $\mathrm{N}$ content in non-nodulated plants significantly increased from $4.9 \pm 0.5$ to $7.0 \pm 0.2 \% \mathrm{~N}$ of grain dry weight as $\mathrm{N}$ fertilization rates increased from 0 to $146 \mathrm{~kg} \mathrm{~N} \mathrm{ha}^{-1}$. Grain N content in nodulated plants exhibited a smaller but significant linear increase from $5.8 \pm 0.6$ to $6.4 \pm 0.1 \%$ (Fig. 3). Irrigation also had an effect on the $\mathrm{N}$ content of grain in nodulated plants, which increased from $5.8 \pm 0.5$ to $6.5 \pm 0.4 \%$ and in nonnodulated plants from $4.9 \pm 0.5$ to $6.2 \pm 0.2 \%$, for rainfed and irrigated plants, respectively. On the other hand, the $\mathrm{N}$ contents of vegetative biomass and roots were not affected by fertilization or irrigation in either 
Table 1 Proportion of $\mathrm{N}$ delivered from $\mathrm{N}_{2}$ fixation (Ndfa) in soybean plants incorporated into aboveground vegetative biomass, roots, and grain

\begin{tabular}{|c|c|c|c|c|}
\hline Treatment & $\begin{array}{l}\text { Fertilizer } \\
\text { application rate } \\
k g N h a^{-1}\end{array}$ & $\begin{array}{l}\text { Aboveground } \\
\text { vegetative biomass } \\
\%\end{array}$ & Roots & Grain \\
\hline F0 & 0 & 11 & 5 & 84 \\
\hline F17 & 17 & 8 & 5 & 87 \\
\hline F34 & 34 & 12 & 1 & 87 \\
\hline F50 & 50 & 10 & 4 & 86 \\
\hline F67 & 67 & 8 & 3 & 89 \\
\hline F84 & 84 & 13 & 5 & 82 \\
\hline F101 & 101 & 34 & 9 & 57 \\
\hline F123 & 123 & 14 & 4 & 81 \\
\hline F146 & 146 & 2 & 0 & 98 \\
\hline Conventional & 0 & 9 & 6 & 86 \\
\hline Irrigated & 9 & 12 & 3 & 85 \\
\hline Average & & $12 \pm 2$ & $4 \pm 1$ & $84 \pm 3$ \\
\hline
\end{tabular}

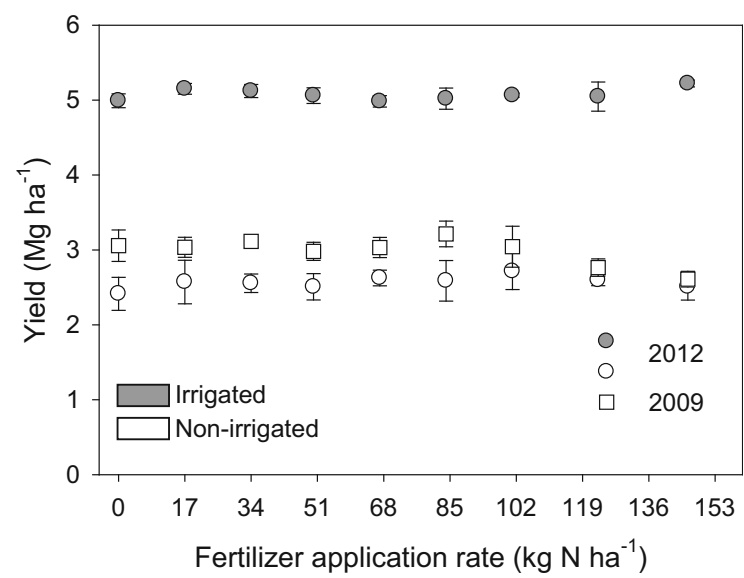

Fig. 2 Yield response to fertilization and irrigation during the 2012 growing season (open and shaded circles) and comparison to non-irrigated yields in 2009 when soybeans were not fertilized (open squares) (mean \pm s.e. $n=4$ )

non-nodulated or nodulated plants, with $\mathrm{N}$ contents of $0.7 \pm 0.1$ and $0.9 \pm 0.1 \%$ of dry weight, respectively.

$\mathrm{N}$ balance, $\mathrm{N}$ credit, and $\mathrm{N}_{\mathrm{r}}$

Soybean $\mathrm{N}$ balance, calculated as the difference between $\mathrm{N}$ removed in harvested grain and the sum of $\mathrm{N}$ acquired from soil and BNF (Eq. 2), was close to zero and not affected by fertilization in any fertilized treatment. Balances ranged from $-29 \pm 29 \mathrm{~kg} \mathrm{~N}$ $\mathrm{ha}^{-1}$ for plots fertilized with $101 \mathrm{~kg} \mathrm{~N}^{-1}$ to $41 \pm$ $24 \mathrm{~kg} \mathrm{~N} \mathrm{ha}^{-1}$ for plots fertilized with $34 \mathrm{~kg} \mathrm{~N}^{-1}$

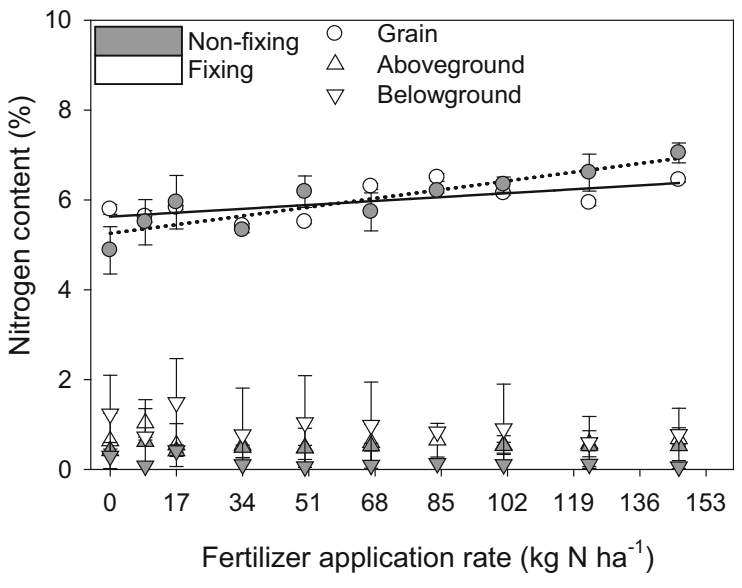

Fig. $3 \mathrm{~N}$ content of in different plant tissues as a function of $\mathrm{N}$ fertilizer rate (average \pm s.e., $n=48$ ). Full symbols represent non-fixing plants. For non-fixing plants (dotted line), $\mathrm{R}^{2}=0.797, p=0.0005$; and for fixing plants (solid line), $\mathrm{R}^{2}=0.445, p=0.0351$

(Table 2). The largest positive balance of $41 \pm 24 \mathrm{~kg} \mathrm{~N} \mathrm{ha}^{-1}$ was calculated for plots that received $34 \mathrm{~kg} \mathrm{~N}^{-1}$ (Table 2). The conventional MCSE and irrigated treatments, on the other hand, exhibited highly positive balances of $76 \pm 16$ and $171 \pm 45 \mathrm{~kg} \mathrm{~N}^{-1}$, respectively. Nitrogen credits for the next rotational crop calculated as the difference between $\mathrm{N}$ removed in harvested grain and the sum of $\mathrm{N}$ acquired from $\mathrm{BNF}$ and $\mathrm{N}$ applied as fertilizer were negative or very low in all treatments (Table 2).

The total production of $\mathrm{N}_{\mathrm{r}}$, which includes $\mathrm{N}$ from $\mathrm{BNF}$ and fertilizer, ranged from an average of 
Table 2 Effect of $\mathrm{N}$ fertilization on the soybean plants' $\mathrm{N}$ relationships, $\mathrm{N}$ balance, and reactive $\mathrm{N}$ production (including error propagation) in no-till fertilized, no-till irrigated, and conventionally managed treatments

\begin{tabular}{|c|c|c|c|c|c|c|c|c|}
\hline Treatment & $\begin{array}{l}\mathrm{N} \text { fertilizer } \\
\text { application rate } \\
K g N h a^{-1}\end{array}$ & $\begin{array}{l}\text { Biological } \\
\mathrm{N} \text { fixation }\end{array}$ & $\begin{array}{l}\text { N Uptake } \\
\text { from Soil }\end{array}$ & Harvest $\mathrm{N}$ & $\mathrm{N}$ balance & $\mathrm{N}$ credit & $\mathrm{N}_{\mathrm{r}}$ & $\begin{array}{l}\text { Yield } \\
\text { weighted } \mathrm{N}_{\mathrm{r}} \\
g N_{r} \mathrm{~kg}^{-1}\end{array}$ \\
\hline F0 & 0 & $84(27)$ & $68(9)$ & $140(20)$ & $13(35)$ & $-55(33)$ & $84(27)$ & $35(11)$ \\
\hline F17 & 17 & $94(30)$ & 69 (14) & $150(21)$ & $14(39)$ & $-38(36)$ & $111(30)$ & $43(12)$ \\
\hline F34 & 34 & 88 (13) & $90(16)$ & 137 (12) & $41(24)$ & $-15(17)$ & $122(13)$ & $48(5)$ \\
\hline F50 & 50 & $59(10)$ & 82 (19) & 139 (13) & $3(25)$ & $-29(17)$ & 109 (10) & $44(4)$ \\
\hline F67 & 67 & $60(18)$ & $115(22)$ & $165(13)$ & $9(31)$ & $-39(22)$ & 127 (18) & $48(7)$ \\
\hline F84 & 84 & $32(9)$ & $145(76)$ & $168(20)$ & $9(79)$ & $-52(22)$ & $116(9)$ & $45(4)$ \\
\hline F101 & 101 & $10(3)$ & $128(24)$ & $167(16)$ & $-29(29)$ & $-56(16)$ & $111(3)$ & $41(2)$ \\
\hline F123 & 123 & 39 (23) & $149(28)$ & $154(9)$ & $34(38)$ & $8(25)$ & $162(23)$ & $62(9)$ \\
\hline F146 & 146 & 37 (10) & $147(22)$ & $162(13)$ & $22(28)$ & $21(17)$ & $183(10)$ & $73(5)$ \\
\hline Irrigated & 0 & $283(25)$ & 158 (19) & $269(33)$ & $171(45)$ & $13(41)$ & $283(25)$ & $57(5)$ \\
\hline Conventional $^{\mathrm{a}}$ & 9 & $80(11)$ & $69(7)$ & $73(9)$ & $76(16)$ & $16(15)$ & $89(11)$ & $47(6)$ \\
\hline
\end{tabular}

${ }^{a}$ Yield weighted $\mathrm{N}_{\mathrm{r}}$ from soybean $\mathrm{BNF}$ (without fertilization) is equal to $43 \pm 6 \mathrm{~g} \mathrm{~N}_{\mathrm{r}} \mathrm{kg}^{-1}$

$\sim 112 \mathrm{~kg} \mathrm{~N} \mathrm{ha}^{-1}$ for $\mathrm{N}$ application rates between 0 and 101 to $162 \pm 23$ and $183 \pm 10 \mathrm{~kg} \mathrm{~N}_{\mathrm{r}} \mathrm{ha}^{-1}$ for application rates of 123 and $146 \mathrm{~kg} \mathrm{~N} \mathrm{ha}^{-1}$. The irrigated treatment produced $283 \pm 25 \mathrm{~kg} \mathrm{~N}_{\mathrm{r}} \mathrm{ha}^{-1}$ and the conventional treatment $89 \pm 11 \mathrm{~kg} \mathrm{~N}_{\mathrm{r}} \mathrm{ha}^{-1}$ (Table 2). Yield-weighted $\mathrm{N}_{\mathrm{r}}$ production exhibited very little variation, with an average production of $45 \pm 2 \mathrm{~g} \mathrm{~N}_{\mathrm{r} \mathrm{kg}} \mathrm{kg}^{-1}$ harvested grain in all but the treatments with 123 and $146 \mathrm{~kg} \mathrm{~N} \mathrm{ha}^{-1}$ application rates, where yield-weighted production was $62 \pm 9$ and $73 \pm 5 \mathrm{~g} \mathrm{~N}_{\mathrm{r} \mathrm{kg}}{ }^{-1}$ grain (Table 2).

\section{Discussion}

Root and aboveground vegetative biomass contributed substantially less BNF (Ndfa) than grain to total $\mathrm{N}_{\mathrm{r}}$ production by soybeans. The root and aboveground vegetative biomass, altogether, contributed $16 \%$ to $\mathrm{N}_{\mathrm{r}}$ production at a zero fertilization level, while grain contributed $84 \%$. At the plant scale, BNF contributed 50,80 , and $90 \%$ to the total $\mathrm{N}$ content in grain, aboveground vegetative biomass, and roots, respectively (Fig. 1). The discrepancy between the Ndfa of specific parts of plant and the relative contribution of plant parts to total $\mathrm{N}_{\mathrm{r}}$ production is due to the low $\mathrm{N}$ content of aboveground vegetative biomass and roots, and a high shoot to root ratio. Therefore, while BNF contributed a significant amount of $\mathrm{N}$ to the aboveground and belowground vegetative biomass $\mathrm{N}$ balances, the total soybean $\mathrm{N}_{\mathrm{r}}$ production was most affected by Ndfa associated with the grain.

Soybean yield was not affected by fertilization; similar results have been shown for other cultivars including Brazilian (Alves et al. 2003). Fertilization, instead, had an effect on the contribution of BNF to plant $\mathrm{N}$, which decreased with added fertilizer $\mathrm{N}$. We found, however, that increasing fertilization positively affected the $\mathrm{N}$ content of the grain, but not that of aboveground vegetative biomass and roots (Figs. 2, 3). Similarly, the decrease in BNF contribution's to plant $\mathrm{N}$ balance due to increasing fertilization was reflected in overall neutral $\mathrm{N}$ balances at all fertilization levels, which translates to little or no $\mathrm{N}$ credits to the next rotational crop (Table 2). Finally, moderate fertilization during early development had no effect on Ndfa over the full growing cycle in contrast to earlier suggestions of increased Ndfa from early fertilization (i.e., van Kessel and Hartley 2000; Ruiz Diaz et al. 2009).

Overall, fertilization (a) reduced the amount of $\mathrm{N}$ fixation, (b) did not contribute to additional yield, and (c) above a modest level of added N, contributed to the environmental $\mathrm{N}_{\mathrm{r}}$ burden.

\section{Effect of $\mathrm{N}$ fertilization on BNF in soybeans}

The contribution of BNF to the $\mathrm{N}$ content of grain, aboveground vegetative, and belowground parts of soybean plants was different under different fertilization 
levels. The contribution of BNF to grain $\mathrm{N}$ decreased linearly from $\sim 50 \%$ with no $\mathrm{N}$ fertilizer to $\sim 16 \%$ at fertilization between 84 and $146 \mathrm{~kg} \mathrm{~N} \mathrm{ha}^{-1}$ (Fig. 1a). The contribution of BNF to the vegetative aboveground biomass $\mathrm{N}$ content also decreased with increasing fertilization, from $80 \%$ at fertilization between 0 and $50 \mathrm{~kg} \mathrm{~N} \mathrm{ha}^{-1}$ to $\sim 10 \%$ at $146 \mathrm{~kg} \mathrm{~N} \mathrm{ha}^{-1}$ (Fig. 1b). The contribution of BNF to root $\mathrm{N}$ content showed a pattern similar to grain as it decreased linearly from $\sim 90 \%$ BNF contribution at zero fertilizer towards a plateau of $\sim 30 \%$ contribution at fertilization levels between 101 and $146 \mathrm{~kg} \mathrm{~N} \mathrm{ha}^{-1}$ (Fig. 1c). The relative importance of the three plant parts to the total Ndfa of the soybean plants averaged 84,12 , and 4 percent for grain, aboveground, and belowground parts, respectively, and showed no clear response to fertilization (Table 1).

While our estimates of the average proportion of BNF contributions to the grain $\mathrm{N}$ content are similar to those found by others (i.e., Salvagiotti et al. 2008; Schipanski et al. 2010; c.f. Alves et al. 2003), our estimates of the BNF contribution to belowground and aboveground vegetative biomass $\mathrm{N}$ and contribution of these plant parts to total soybean Ndfa are significantly different from the reported values of 24-40\% for roots and $60 \%$ for aboveground residuals (Herridge et al. 2008; Rochester et al. 1998; Unkovich and Pate 2000) currently used for global $\mathrm{N}$ budgets calculations.

In contrast to the recommended application rate of $\sim 50 \mathrm{~kg} \mathrm{~N}^{-1}$ (i.e., International Plant Nutrition Institute 2014) and earlier occasional reports of a yield response to $\mathrm{N}$ fertilizer application (e.g., Gan et al. 2003; Heatherly and Elmore, 2004; Salvagiotti et al. 2008), we found no yield response to $\mathrm{N}$ fertilizer in either rainfed or irrigated treatments (Fig. 2). What might explain this lack of response? Since BNF is an energy and carbon (C) demanding process with an average cost of $6 \mathrm{~g} \mathrm{C}$ per $1 \mathrm{~g}$ fixed $\mathrm{N}$ (Vance and Heichel 1991), one might expect that when plants avoid this cost they would be able to allocate more carbon and energy to reproductive tissue (i.e. grain). Two explanations seem plausible: First, there may have been an additional limiting factor at our site other than $\mathrm{N}, \mathrm{P}, \mathrm{K}$, and water. This possibility is unlikely, however, since standard agronomic soil tests at our site have not noted any trace element deficiencies (http:// lter.kbs.msu.edu/datatables/354). Second, energy intensive $\mathrm{N}$ compounds may have accumulated in grain without contributing to the production of grain mass. If this were the case, the grain $\mathrm{N}$ content of the $\mathrm{N}$-fixing plants would have increased, which was, in fact, the case: grain $\mathrm{N}$ content increased from $5.8 \pm 0.1$ to $6.4 \pm 0.1 \%$ with increasing levels of fertilization (Fig. 3).

The grain $\mathrm{N}$ response of the non-fixing soybean plants to $\mathrm{N}$ fertilization was much stronger than that of the $\mathrm{N}$-fixing plants (Fig. 3). The grain $\mathrm{N}$ content of the non-fixing plants steadily increased with increased $\mathrm{N}$ fertilization levels by more than $2 \%$, from $4.9 \pm 0.5$ to $7.1 \pm 0.2 \% \mathrm{~N}$. This can be explained by the interplay between the additional carbon cost of BNF and $\mathrm{N}$ availability. Under high fertilization levels the $\mathrm{N}$-fixing plants, which cannot completely down regulate resource-intensive BNF (Silsbury 1977), maintained $\mathrm{N}$ fixation rates of $\sim 16 \%$ despite high soil $\mathrm{N}$ availability, and accumulated less $\mathrm{N}$ in grain at the highest fertilization level as compared to non-fixing plants (6.4 vs. $7.1 \%$; Fig. 3).

Even with high yields during a more favorable climate year our soybeans would have been unlikely to have responded to fertilizer $\mathrm{N}$. Yields of $6.7 \mathrm{Mg} \mathrm{ha}^{-1}$ (100 bu acre ${ }^{-1}$ ) would require a total $\mathrm{N}$ uptake of $\sim 380 \mathrm{~kg} \mathrm{~N}^{-1}$; based on this study a minimum of $51 \%$ of this total would have been satisfied by BNF, leaving $\sim 190 \mathrm{~kg} \mathrm{~N} \mathrm{ha}^{-1}$ to be provided by soil organic matter mineralization, which is within the mineralization supply of these moderately fertile loams (Millar and Robertson 2015).

\section{Effect of $\mathrm{N}$ fertilization and irrigation on $\mathrm{N}_{\mathrm{r}}$ produced by soybean cultivation}

Fertilization rates of up to $101 \mathrm{~kg} \mathrm{~N} \mathrm{ha}^{-1}$ affected $\mathrm{N}_{\mathrm{r}}$ production by soybean, which ranged between $84 \pm 27$ and $127 \pm 18 \mathrm{~kg} \mathrm{~N}_{\mathrm{r}}$ ha $^{-1}$ mainly due to fertilizer inputs. In highly fertilized and irrigated treatments, $\mathrm{N}_{\mathrm{r}}$ production was also high, due to high $\mathrm{N}$ fertilizer inputs rather than increased grain delivered $\mathrm{Nr}$, except in the irrigated treatment. When scaled by grain yield there were no differences among treatments except at the highest fertilization levels. The estimated $\mathrm{N}_{\mathrm{r}}$ production in the MCSE conventionally managed soybean crop was $89 \pm 11 \mathrm{~kg} \mathrm{~N}_{\mathrm{r}} \mathrm{ha}^{-1}$ and is similar to the $111 \mathrm{~kg} \mathrm{~N}_{\mathrm{r}}$ estimated by Salvagiotti et al. (2008) despite a relatively dry growing season during our experiment.

During the growing season (June-October) rainfall at our site was $226 \mathrm{~mm}$ or $60 \%$ of normal precipitation. 
Yields were consequently depressed by $14 \%$ on average (range of 4-21\%; Fig. 2) as compared to 2009 , when rainfall $(382 \mathrm{~mm})$ was slightly more than the long-term growing season average of $369 \mathrm{~mm}$ for our site (NOAA 2009; lter.kbs.msu.edu/datatables/7). The drier conditions and lower yields in 2012 could potentially lead to an underestimation of $\mathrm{N}_{\mathrm{r}}$ production. However, they did not seem to have a major effect on the BNF contribution to soybean $\mathrm{N}$ balance (i.e., Fig. 1).

\section{Regional perspective}

Based on an average US soybean production between 2002 and 2012 (FAOSTAT 2014; $2.8 \pm 0.1 \mathrm{Mg} \mathrm{ha}^{-1}$ ), which was very similar to soybean yield at our site for $2012\left(2.6 \pm 0.1 \mathrm{Mg} \mathrm{ha}^{-1}\right)$, and our estimate of $\mathrm{N}_{\mathrm{r}}$ from the conventionally managed plots, we can calculate the total $\mathrm{N}_{\mathrm{r}}$ delivered to the environment due to soybean cultivation. Reactive $\mathrm{N}$ production from the conventionally tilled plots in 2012 was $69 \mathrm{~kg} \mathrm{~N}_{\mathrm{r}} \mathrm{ha}^{-1}$ in grain, $7 \mathrm{~kg} \mathrm{~N}_{\mathrm{r}} \mathrm{ha}^{-1}$ in aboveground vegetative biomass, and $4 \mathrm{~kg} \mathrm{~N}_{\mathrm{r}}$ ha $^{-1}$ in roots. Total $\mathrm{N}_{\mathrm{r}}$ production due to soybean BNF therefore sums to $80 \pm 11 \mathrm{~kg} \mathrm{~N}_{\mathrm{r}} \mathrm{ha}^{-1}$ (excluding fertilization; Table 2). This translates to $43 \pm 6 \mathrm{~g} \mathrm{~N}_{\mathrm{r} \mathrm{kg}} \mathrm{kg}^{-1}$ grain (Table 2). US soybean production between 2002 and 2012 averaged $82 \times 10^{6}$ $\pm 2 \times 10^{6} \mathrm{Mg}$ (USDA NASS 2014; FAOSTAT 2014), which translates to $3.5 \pm 0.5 \mathrm{Tg}$ of new $\mathrm{N}_{\mathrm{r}}$.

Our estimate of $\mathrm{N}_{\mathrm{r}}$ based on the differential contribution to whole soybean plant Ndfa by different plant parts (i.e., grain, aboveground vegetative biomass, and roots) is $\sim 37 \%$ lower than the $5.7 \mathrm{Tg} \mathrm{N} \mathrm{N}_{\mathrm{r}}$ estimated for US soybean production by Herridge et al. (2008) based on 2005 yields. The difference stems from a) their assumption of $60 \% \mathrm{Ndfa}$ for grain, aboveground biomass and roots of soybeans versus our different percentages for different parts of the plant (Fig. 1, Table 2), b) their assumption of $3 \% \mathrm{~N}$ in parts of the plants other than grain versus our $\sim 1 \% \mathrm{~N}$ as measured in the field, and c) their estimate of total crop biomass $\mathrm{N}$ based on multiplying shoot $\mathrm{N}$ by a factor of 1.5 , which translates to an estimated contribution of belowground biomass $\mathrm{N}$ to the overall soybean $\mathrm{N}$ budget of $50 \%$ versus our measured contribution of $\sim 4 \%$ (Table 1 ).

Current global estimates of $\mathrm{N}_{\mathrm{r}}$ from BNF, calculated by Herridge et al. (2008) are $16.4 \mathrm{Tg}$ N. If we assume similar tissue differentiation as for this study, the global estimate is likely overestimated by $37 \%$, such that global $\mathrm{N}$ fixation from soybean BNF is likely
$10.4 \mathrm{Tg} \mathrm{N} \mathrm{N}_{\mathrm{r}}$. This value is about $\sim 18 \%$ of terrestrial BNF prior to human alternation of the $\mathrm{N}$ cycle (Vitousek et al. 2013).

\section{Conclusions}

Nitrogen fertilization across a wide range of fertilizer levels did not affect soybean yields but resulted in higher grain $\mathrm{N}$ content and diminished biological $\mathrm{N}$ fixation. Above modest fertilizer levels, grain $\mathrm{N}$ content increased with no further attenuation of $\mathrm{N}$ fixation, leading to higher $\mathrm{N}_{\mathrm{r}}$ production.

Fertilization affected the $\mathrm{N}$ content of plant tissues differently: in grain, fertilizer decreased the percent of $\mathrm{N}$ fixed from 49 to $16 \%$, in aboveground vegetative biomass from 77 to $11 \%$, and in roots from 88 to $41 \%$. Overall, fertilizer $\mathrm{N}$ reduced $\mathrm{N}$ fixation in soybean plants from 84 to $34 \%$.

The contribution of root and vegetative biomass to total plant $\mathrm{N}$ accumulation was $\sim 20 \%$ of that for grain. Extrapolating tissue-specific values to US soybean production provides an estimate of $3.5 \pm 0.5 \mathrm{Tg}$ of new $\mathrm{N}_{\mathrm{r}}$ added to the environment annually, $\sim 37 \%$ lower than prior estimates that did not differentiate tissue source.

Our overall results underscore the general futility of adding $\mathrm{N}$ fertilizer to modern soybean varieties, even in starter amounts, and as well its additional cost to environmental $\mathrm{Nr}$ loading.

Acknowledgments We thank E.K. Peregrine (USDA ARS, Urbana, IL) for providing non-nodulating germplasm and J. Simmons for agronomic field assistance. We also thank GreenCare Fertilizers, Chicago, IL, for providing the $\mathrm{N}$-free micronutrient solution. Financial support for this work was provided by the DOE Office of Science (DE-FC02-07ER64494, KP1601050) and Office of Energy Efficiency and Renewable Energy (DE-AC05-76RL01830, OBP 20469-19145), the US National Science Foundation LTER program (DEB 1027253), and MSU AgBioResearch.

Open Access This article is distributed under the terms of the Creative Commons Attribution License which permits any use, distribution, and reproduction in any medium, provided the original author(s) and the source are credited.

\section{References}

Alves BR, Boddey R, Urquiaga S (2003) The success of BNF in soybean in Brazil. Plant Soil 252:1-9 
Blesh J, Drinkwater LE (2013) The impact of nitrogen source and crop rotation on nitrogen mass balances in the Mississippi River Basin. Ecol App 23:1017-1035

FAO (2007) At http://www.fao.org/fileadmin/user_upload/tcas/ publications/policy_assistance_series_3.pdf. Accessed 3 November 2014

FAOSTAT (2014) At http://faostat.fao.org/site/567/DesktopDefault. aspx?PageID=567\#ancor. Accessed 26 May 2014

Galloway JN, Dentener FJ, Capone DG, Boyer EW, Howarth RW, Seitzinger SP, Asner GP, Cleveland CC, Green PA, Holland EA, Karl DM, Michaels AF, Porter JH, Townsend AR, Voosmarty CJ (2004) Nitrogen cycles: past, present, and future. Biogeochemistry 70:153-226

Gan Y, Stulen I, van Keulen H, Kuiper PJC (2003) Effect of N fertilizer top-dressing at various reproductive stages on growth, $\mathrm{N}_{2}$ fixation and yield of three soybean (Glycine $\max ($ L.) Merr.) genotypes. Field Crop Res 80:147-155

Heatherly LG, Elmore RW (2004) Managing inputs for peak production. In: Boerma HR, Specht JE (eds) Soybeans: improvement, production, and uses. American Society of Agronomy, Madison, pp 451-537

Herridge D, Peoples M, Boddey R (2008) Global inputs of biological nitrogen fixation in agricultural systems. Plant Soil 311:1-18

International Plant Nutrition Institute (2014) http://www. nutrientstewardship.com/implement-4rs/article/do-highyielding-soybeans-need-be-fertilized-nitrogen?category =2\&region=12 Accessed 25 April 2014

Martinelli L, Howarth R, Cuevas E, Filoso S, Austin A, Donoso L, Huszar V, Keeney D, Lara L, Llerena C, McIssac G, Medina E, Ortiz-Zayas J, Scavia D, Schindler D, Soto D, Townsend A (2006) Sources of reactive nitrogen affecting ecosystems in Latin America and the Caribbean: current trends and future perspectives. Biogeochemistry 79:3-24

Millar N, Robertson GP (2015) Nitrogen transfers and transformations in row-crop ecosystems. In: Hamilton SK, Doll JE, Robertson GP (eds) The ecology of agricultural landscapes: long-term research on the path to sustainability. Oxford University Press, New York

NOAA (2009) www.crh.noaa.gov/images/grr/climate/2009_ Annual_Climate_Summary.pdf assessed on 4 April 2014

Peoples MB, Herridge DF, Ladha JK (1995a) Biological nitrogen fixation: an efficient source of nitrogen for sustainable agricultural production? Plant Soil 174:3-28

Peoples MB, Gault RR, Lean B, Sykes JD, Brockwell J (1995b) Nitrogen fixation by soybean in commercial irrigated crops of central and southern New South Wales. Soil Biol Biochem 27:553-561
Pioneer at: https://www.pioneer.com/home/site/us/agronomy/ library/nitrogen-fertilizer-for-soybean/. Accessed At 19 November 2014

Robertson GP, Hamilton SK (2015) Conceptual and experimental approaches to understanding agricultural ecosystems. In: Hamilton SK, Doll JE, Robertson GP (eds) The ecology of agricultural landscapes: long-term research on the path to sustainability. Oxford University Press, New York

Ruiz Diaz DA, Pedersen P, Sawyer JE (2009) Soybean response to inoculation and nitrogen application following longterm grass pasture. Crop Sci 49:1058-1062

Salvagiotti F, Cassman KG, Specht JE, Walters DT, Weiss A, Dobermann A (2008) Nitrogen uptake, fixation and response to fertilizer $\mathrm{N}$ in soybeans: a review. Field Crop Res 108:1-13

Schipanski M, Drinkwater L, Russelle M (2010) Understanding the variability in soybean nitrogen fixation across agroecosystems. Plant Soil 329:379-397

Silsbury JH (1977) Energy requirement for symbiotic nitrogen fixation. Nature 267:149-150

Smil V (1999) Nitrogen in crop production: an account of global flows. Global Biogeochem Cycl 13:647-662

Soystat (2013) At http://soyohio.org/wp-content/uploads/2013/ 07/ASA_SoyStats_fnl.pdf. Accessed at 3 November 2014

Syswerda SP, Basso B, Hamilton SK, Tausig JB, Robertson GP (2012) Long-term nitrate loss along an agricultural intensity gradient in the Upper Midwest USA. Agric, Ecosys Environ 149:10-19

University of Minnesota at: http://www.extension.umn.edu/ agriculture/nutrient-management/nutrient-lime-guidelines/ fertilizer-recommendations-for-agronomic-crops-in-minne sota/soybean/. Accessed at 19 November 2014

Unkovich MJ, Pate JS (2000) An appraisal of recent field measurements of symbiotic $\mathrm{N}_{2}$ fixation by annual legumes. Field Crop Res 65:211-228

USDA NASS (2014) http://www.nass.usda.gov/ Assessed 25 April 2014

van Kessel C, Hartley C (2000) Agricultural management of grain legumes: has it led to an increase in nitrogen fixation? Field Crop Res 65:165-181

Vance CP, Heichel GH (1991) Carbon in $\mathrm{N}_{2}$ fixation: limitation or exquisite adaptation. Annu Rev Plant Phvsiol Plant Mol Bio 42:373-392

Vitousek PM, Menge DNL, Reed SC, Cleveland CC (2013) Biological nitrogen fixation: rates, patterns and ecological controls in terrestrial ecosystems. Phil Trans Royal Soc B 368: 1621 